\title{
Competitiveness Management of Educational Services in Higher Education
}

\author{
Alexander Valentinovich Kosevich ${ }^{1}$, Veronika Olegovna Kozhina ${ }^{1}$, Galina Viktorovna Pinkovskaya ${ }^{2}$, Olga Igorevna \\ Rybyakova $^{3}$, Olga Yevgenievna Lebedevaa ${ }^{4}$ \\ ${ }^{I}$ International Institute of Economics and Law, Rubtsovskaya Naberezhnaya, 3, Moscow, 105082, Russia \\ ${ }^{2}$ K. G. Razumovsky Moscow State University of technologies and management (the First Cossack University), Institute of social- \\ humanitarian technologies, Narodnogo opolcheniya St., 38/2, Moscow, 123298, Russia \\ ${ }^{3}$ Omsk State Pedagogical University, Naberezhnaya Tukhachevskogo, 14, Omsk, 644099, Russia \\ ${ }^{4}$ Institute for Tourism and Hospitality, Kronstadt Blvd., 32a, Moscow, 125438, Russia
}

\begin{abstract}
The article substantiates key components of competitiveness management of educational services in higher education. The research outcomes have allowed identifying the main competitive advantages of educational services, which include the availability of additional educational services, the ability to participate in students' exchange programs in home country and abroad, practical significance, assistance with employment, and reliable material and technical base. In the context of an integrated approach, the article proposes the organizational and economic mechanism for competitiveness management of educational services, which includes institutional support, economic security, social security, as well as technical and regulatory support. In order to solve the problem of inefficient use of financial resources, it is proposed to establish committees at the state level, the members of which will be representatives of the public sector, international community, and other experts in this field.
\end{abstract}

Keywords: management, competitiveness, educational service, higher education, state, quality, academic teaching staff.

\section{Introduction}

At the present stage of human development, human capital becomes one of the leading factors of production, while higher education is one of the strategic resources. This thesis defines the fundamental aspects of the influence of the educational system on the economy of the country, the effective functioning of which should be insured first and foremost. However, certain factors exist that do not contribute to the development of higher education. Economic instability does not incite development. This is the reason for the unsatisfactory financial condition of the educational and science system in general, as well as the low level of wages of academic teaching staff. The needs of the society and integration processes stimulate reforms in the field of education. The state's main concern for the development of education is one of the longawaited steps.

Since any activity is accompanied by the adoption of decisions and the implementation of new goals, this challenges the scientific and educational sphere, which seeks to match the educational system in developed democratic countries. Nevertheless, Russia still faces the threat of remaining among the states with a low level of progress. The reason for such development is the inability to resist the negative impact of globalization.

Taking this into account, Russia should strive to provide more fully its citizens with quality and competitive educational services, as well as to uncover the opportunities for increasing the rates of economic growth through the production of highly qualified specialists from higher education institutions.

At the same time, an important challenge of society is reforming and modernizing education, because education is the link among an individual, society, state, and business, and influences the balance of their relationships. The educational sphere to a greater extent meets not only the needs but also the interests of an individual, prepares a student for adult life, adapts to society, and educates a conscious citizen.

The study of the competitiveness management issues in educational services of higher education is reflected in the writings of E. A. Ermakova [1], S. M. Kornev [2], I. T. Nasretdinov [3], A. N. Nosyreva [4], I. V. Olkhovik [5], and I. A. Yumasheva [6]. The importance and relevance of the problems under consideration and their insufficient study led to the choice of the present research topic.

\section{Methods}

To solve the goals and objectives set in the work, the following research methods were used: the dialectical method of cognition of economic phenomena, which made it possible to identify the essence of the key concepts of this study; the comparative method was used to compare the indicators that determined the competitiveness level of higher education institutions; the economic and statistical method allowed studying the development trends in the domestic market of educational services.

The information base of the research included legislative and regulatory acts, statistical materials of the state authorities and local government, scientific publications of Russian and foreign scientists on the problems of competitiveness management of educational services in higher education $[7,8,9]$.

In the course of the study, approaches to managing the competitiveness of educational services in the field of higher education 
were developed, and managing strategies were substantiated based on educational services quality parameters. Among other things, the task was to justify the methods for assessing the factors affecting the competitiveness of educational services and to formulate the main development paths of the higher education system.

\section{Results}

Competitiveness of educational services is a comparative characteristic of their consumer and cost parameters in comparison with the services of educational business rivals. Therefore, the competitiveness of educational services can be viewed through the prism of the competitiveness of a higher education institution, which provides and offers these services in the higher education market (Fig 1).

Competitiveness of educational services is a generalized charac-
teristic of advantages in the context of indicators reflecting total expenses and satisfaction of consumers' needs

\begin{tabular}{|c|c|c|}
\hline $\begin{array}{c}\text { Organizational and } \\
\text { economic indica- } \\
\text { tors: quality of } \\
\text { conformance with } \\
\text { standards, norms, } \\
\text { and regulations for } \\
\text { the provision of } \\
\text { educational ser- } \\
\text { vices }\end{array}$ & $\begin{array}{c}\text { Economic indica- } \\
\text { tors: service fee, } \\
\text { transportation } \\
\text { costs, operating } \\
\text { and maintenance } \\
\text { costs, and per- } \\
\text { sonnel training } \\
\text { costs }\end{array}$ & $\begin{array}{c}\text { Social and or- } \\
\text { ganizational } \\
\text { indicators: ac- } \\
\text { counting for the } \\
\text { social structure } \\
\text { of consumers } \\
\text { and national } \\
\text { characteristics }\end{array}$ \\
\hline $\begin{array}{c}\text { The main factors for improving educational services competitive- } \\
\text { ness: }\end{array}$ & $\begin{array}{c}\text { 1. } \\
\text { 1. Improving applied educational technologies and educational } \\
\text { programs; }\end{array}$ \\
2. Creating fundamentally new types of educational services and \\
differencing the existing ones \\
satisfaction of market customers with the offered services and the \\
effectiveness of educational activities
\end{tabular}

Fig. 1: The main factors for improving the educational services competitiveness in higher education

At the same time, the competitiveness of educational services provides the following advantages: the availability of additional educational services; the opportunity to be involved in exchange programs in the domestic country and abroad; practical significance; assistance with employment; and appropriate material and technical base. Therefore, the authors consider it appropriate to characterize each competitive advantage both at the macrolevel and microlevel. The authors understand the macrolevel with respect to the educational services offered by Russia in the global education market, while the microlevel is a variety of educational services that are concentrated internally in the country, thus creating competition among domestic higher education institutions.

Some educational services have their own special significance at the macrolevel, for example, the provision of services in English or other foreign languages, if it is provided in the learning process This advantage is undeniable because it attracts foreign students, which in turn popularizes Russia in the world market of educational services. Also, one cannot avoid considering the work with postgraduate degree seekers that plays a particularly important role when the subject concerns innovative research.

When considering the microlevel, the authors talk about a second higher education or retraining, which essentially contribute to the demand for educational services. Teaching subjects in foreign languages expands the professional and linguistic knowledge of a student, who increases further his/her knowledge level through educational services after graduation. Preparation for entrance examinations and external independent testing contributes to the influx of consumers, especially when it comes to creative competitions and tests in physical training because this immediately focuses on those requirements, which are basic when passing the examinations.

Conducting open and closed lectures involving renowned figures, businessmen, and scientists attracts listeners and provides a positive image of the higher institution. In addition, higher education institutions may offer consumers of educational services to participate in international student exchange and internship programs. Through these activities, students share experiences, which, in turn, in course of time can be adapted and implemented in their home country and region. Such events also contribute to the development of international cooperation and joint research cooperation.

Practical significance is one of the competitive advantages, which affects the decision of an applicant when choosing an educational service and corresponding institution providing this service. After all, it is practical significance that is the ultimate goal after the completion of the educational process. Unfortunately, in the authors' opinion, the practicality of the acquired knowledge gained through many educational services does not correlate with time and relevance. Often, approaches and methods, as well as software offered during the training, are outdated and are not widely used in the contemporary world.

One of the problems a graduate faces is the problem of employment. It is related to a number of reasons, such as lack of experience, on the one hand, and the reluctance of employers to teach young professional, on the other hand. The authors believe that another reason is the oversaturation of the market by certain specialists. This concerns university specialists graduated from the faculties of economics, law, and international relations.

As a result, many young professionals choose jobs outside of their area of expertise since market demand is lower than supply. At the same time, a number of activities can strengthen the effectiveness of the job searching process for a student and a graduate. These activities include holding career days, where companies can represent themselves and close open vacancies with young professionals; holding contests and competitions by business entities with possible further employment; and holding open days in the framework of the educational process, where a consumer of educational services has the opportunity to become familiar with the actual work process.

It is also impossible to avoid noting the activities of employment departments, which can work closely with enterprises and institutions to facilitate the job search process. Also, such service departments can provide a number of additional services, such as personal counseling, to determine the personal skills and abilities of a student or graduate, selecting vacant offers, and preparing resumes attractive for an employer, as well as preparing graduates for the interview.

Another significant competitive advantage is the material and technical base, which includes buildings, structures, land, communications, equipment, vehicles, service housing, and other assets. However, this applies directly to an educational institution. While considering these assets from the standpoint of providing educational services, one can distinguish the latest curricula, full provision of textbooks and manuals, a sufficient number of computer labs with appropriate modern computer software necessary to obtain the appropriate knowledge and skills, high-speed access to the Internet, and equipping laboratories for conducting experiments.

Practice has shown that the competitiveness management mechanism of educational services consists of economic and organizational parts, which include the following: institutional support, i.e., the availability of state and non-state entities, which ensure the 
effective management of educational services; economic support, namely the interrelated actions for achieving the set goals towards obtaining a certain level of competitiveness; social security, i.e. availability of personnel, who provide educational services at a competitive level, as well as employees, who carry out such activities indirectly; technical support, namely a set of technologies, technical and technological support, materials, etc.; regulatory support, i.e. a set of laws, regulations, decisions, and other legal documents, which ensure the competitiveness of the educational services market.

At the same time, to effectively manage the competitiveness of educational services, it is necessary to analyze the higher education management system, identify the object and subjects, characterize each of the elements, and determine their role in this process.

\section{Discussion}

The reliability of the presented approaches to the competitiveness management of educational services in higher education is confirmed by the fact that higher education is characterized by the following trends: an imbalance between demand and supply in the educational services market, which results in an increase in the number of graduates of unclaimed professions; a decrease in the quality factors of higher education institutions, in particular the qualifications of graduates; presence of resource crisis, which is manifested not only in the reduction of funding from the state budget, but also in the commercialization of educational activities; and a steady trend towards mass education along with the deterioration of the qualification and age structure of employment $[10,11,12]$.

Experience has shown that consumers have significant impact on the competitiveness of educational services. They directly determine services competitiveness, which is realized through the choice of educational services. There are several factors that affect the choice of educational services by a consumer, namely: consumers' own tastes, which are a subjective factor; the possibility of employment is almost the main factor when choosing educational services; the prestige of the chosen profession; as well as the advice of parents.

Consumers play an important role in the competitiveness of educational services in higher education. In this case, higher education institutions, as well as individuals and legal entities produce services. This group affects the competitiveness of educational services through the following factors: academic teaching staff, material and technical base, and assistance in employment.

At the same time, if consumers value employment assistance, service producers can accelerate this process through their own relationships established with enterprises and institutions. In higher education institutions this is done by departments of employment, which receive direct requests from recruiters and help graduates to find occupational work. Also, such communication often simplifies employment, because between the company and the educational institution there may be an agreement on certain quotas during the recruitment

Another factor influencing educational services competitiveness is the state. State exerts its influence through the adoption of statutory and regulatory enactments (laws, legislation, regulations, decrees, and orders). These documents determine organizational, financial, legal and other bases of educational services market functioning in higher education. Nevertheless, these normative legal documents not only lay the legal aspects of the market functioning but also are more radical in nature. In this aspect, it is possible to distinguish standards that relate to educational programs and curricula, as well as the system ensuring the education quality.

\section{Conclusion}

Summing up, it can be noted that the competitiveness of educational services is the ability to meet the needs of the educational services subjects, as well as their adaptation to the results of scientific and technical progress, and the ability to compete in the external and internal market of educational services during a certain period of time.

The outcomes of the present research allowed identifying the main competitive advantages of educational services, such as the availability of additional educational services, the ability to participate in students' exchange programs at home country and abroad, practical significance, assistance with employment, and reliable material and technical base.

In the context of an integrated approach, the authors propose an organizational and economic mechanism for competitiveness management of educational services, which includes institutional support, economic support, social security, technical support, and regulatory support. In order to solve the problem of inefficient use of financial resources, it is necessary to establish committees at the state level, the members of which will be represented by individuals of the public sector, representatives of the international community, and other experts in this field.

It is also necessary to reduce the number of higher education institutions. This will allow reducing significantly the number of higher education institutions with a low level of educational services quality. It is clear that such reduction can be implemented in two ways: 1) the complete elimination of a higher education institution as a result, for a certain period of time it will be possible to carry out the redistribution of funds allocated to the activities of liquidated higher education institutions; and 2) reorganization of a higher education institution, during which a part of the organizational structure is liquidated, while the rest can be affiliated with another educational institution. Such reformation is less painful as compared to the first option, where students are transferred to other educational institutions to continue receiving educational services, while academic and teaching staff and other personnel are left without jobs.

An important direction for improving educational services competitiveness is monitoring the quality of academic and teaching staff, i.e. the reform in the field of higher education should be carried out not only in the executive bodies of the highest levels but also at the places of implementation of educational services. Such monitoring can be carried out every two years. It will consist in the assessment of the quality of educational services provided by the academic and teaching staff.

\section{References}

[1] Ermakova EA (2016), Mesto sociologicheskogo monitoringa $\mathrm{v}$ sisteme upravleniya vuzom [Sociological monitoring in the university management system] [Text]. Economics. Sociology. Law, 3, 50-57.

[2] Kornev S M (2014), Upravlenie kachestvom obrazovatel'nyh uslug kak faktor povysheniya konkurentosposobnosti obrazovatel'noj organizacii [Educational services quality management as a factor of increasing the competitiveness of educational organization]. Academic Bulletin, 2 (28), 305-311.

[3] Nasretdinov I T (2017), Metodicheskie podhody k upravleniyu konkurentosposobnost'yu obrazovatel'noj organizacii na osnove povysheniya kachestva obrazovatel'nyh uslug [Methodical approaches to competitiveness management of the educational organization based on the improvement of educational services quality]. Bulletin of the Russian University of Cooperation, 2(28), 57-60.

[4] Nosyreva AN \& Anufrieva EA (2016), Upravlenie konkurentosposobnost'yu obrazovatel'noj uslugi (na primere vuzov ZATO) [Competitiveness management of educational services (evidence from the higher education institutions of closed administrativeterritorial unit]. Socio-Economic Sciences and Humanities, 13, 1316 
[5] Olkhovik IV (2015), Mezhdunarodnye obrazovatel'nye uslugi kak faktor konkurentosposobnosti VUZa [International educational services as a factor of university competitiveness]. Business, Management, and Law, 2(32), 87-90.

[6] Yumasheva IA (2011), Processnyj podhod k upravleniyu kachestvom obrazovatel'noj uslugi v sisteme obespecheniya konkurentosposobnosti sistemy vysshego professional'nogo obrazovaniya [Process approach to quality management of educational services in the system ensuring competitiveness of higher professional education]. Intelligence. Innovation. Investment, 4, 41-47.

[7] Karpov VV, Kovalev VA, Korableva AA, Khairov BG \& Lebedev KA (2017), Methodical framework of forming territorial innovation clusters based on import substitution mechanism. Espacios, 38(58), 11.

[8] Saadulaeva TA, Lebedeva OE, Pinkovskaya GV, Shaimardanova LK \& Gorshkova LV (2018), Statistical approaches to the assessment of qualitative parameters of services market. International Journal of Pure and Applied Mathematics, 119(16), 3839-3843.

[9] Zavalko NA, Kozhina VO, Zhakevich AG, Matyunina OE \& Lebedeva OE (2017), Methodical approaches to rating the quality of financial control at the enterprise. Quality: Access to Success, 18(161), 69-72.

[10] Cherkasov IL, Seredina MI, Mishurova OI, Adashova TA \& Lebedeva OYe (2017), The effect of international tourism on the development of global social-economic processes. Journal of Environmental Management and Tourism, 8, 6(22), 1166-1170.

[11] Kosevich AV, Matyunina OE, Zhakevich AG, Zavalko NA \& Lebedev KA (2016), Methodology to estimate the financial market condition. Journal of Advanced Research in Law and Economics, 7(7), 1749-1753.

[12] Seredina MI, Tretyakova GV, Oberemko TV, Kozhina VO \& Lebedev KA (2017), Impact of external labor migration on labor market development. Journal of Advanced Research in Law and Economics, 8(2), 596-600. 